\title{
The Biological Basis of Culture: Did Nietzsche pre-empt Damasio?
}

\author{
By \\ Paddy Twigg
}

\section{Summary}

This essay responds to a challenge to examine the possible connections between two quotations, one from Friedrich Nietzsche, 1886, and the other from Antonio Damasio, 2018, each proposing a physical basis for cultural difference. The first emphasises tempo and metabolism while the second emphasises the ability to make images, affect and consciousness as the origin of culture. Both theories seem to be based on neurophysiological processes, though Nietzsche's use of "metabolism" may be metaphorical and not related to physiology at all. Both philosophers look back to earlier thinkers, Nietzsche to Aristotle (4C BCE), and Damasio to René Descartes (1637, 1641), Baruch Spinoza (1677), David Hume (1740) and William James (1884). 


\section{Introduction}

"The most difficult thing about translating from one language into another is the tempo of its style, which is rooted in the character of the race - physiologically speaking, in the average tempo of its "metabolism". There are honestly intended translations which, as involuntarily coarse versions of the original, are almost misrepresentations, simply because its brave and cheerful tempo, which springs over and neutralizes everything dangerous in things and words, cannot be translated."

Friedrich Wilhelm Nietzsche, Beyond Good and Evil, 1886, translated by R. J. Hollingdale

"All mental faculties intervene in the human cultural process, but [...] I chose to highlight the ability to make images, affect, and consciousness, because cultural minds are not conceivable without such faculties. Memory, language, imagination, and reasoning are leading participants in cultural processes, but require image making. As for the creative intelligence responsible for the actual practices and artifacts of cultures, it cannot operate without affect and consciousness. Curiously, affect and consciousness also happen to be the faculties that got away, forgotten in the throes of the rationalist and cognitive revolutions. They deserve special attention."

Damasio, Antonio R., The Strange Order of Things: Life, feeling and the making of cultures.

Antonio Damasio became well-known with the publication of his first book, Descartes' Error. Becoming increasingly famous, he developed his theories over successive books, culminating (so far) in The Strange Order of Things in 2018. ${ }^{1}$ The Portuguese-American neuroscientist, currently also Professor of Psychology, Philosophy, and Neurology at the University of Southern California, has been awarded honorary doctorates and prizes all over the world for his ground-breaking integration of neuroscience with philosophy of the mind and culture. ${ }^{2}$ In his writing, Damasio has set out strong evidence for his argument that culture has its basis in human biology. However, his theories have sparked not just praise but also controversy. ${ }^{3}$

\footnotetext{
${ }^{1}$ Antonio R. Damasio, Descartes' Error: Emotion, Reason and the Human Brain, New York: Grosset/Putnam, 1994. Antonio R. Damasio, The Strange Order of Things: Life, feeling and the making of cultures, New York: Pantheon, 2018.

${ }^{2}$ University of Southern California faculty profile: https://dornsife.usc.edu/cf/faculty-andstaff/faculty.cfm?pid=1008328

${ }^{3}$ Damasio does not seem to accept criticism easily. For instance, he responded to a very carefully worded, sophisticated and well-supported review of his book Looking for Spinoza with the following: “...it is reasonable to wonder what could possibly have caused this misunderstanding. Out of courtesy and modesty, perhaps I should simply take the blame and say that it is all my fault, that I simply should have made my writing more clear so that P \& W would not be so confused. Unfortunately, it is not so easy. I have no doubt I could have made myself more clear, but perhaps some of the misunderstandings come from reading the material with an attitude that I can only describe as militant" (Antonio Damasio, Transparent Feelings: A reply to Jaak Panksepp and Douglas Watt, in Jaak Panksepp, Antonio Damasio \& Heidi M. Ravven, 'Book Reviews', Neuropsychoanalysis, 5:2, 2008, 201-230, DOI: 10.1080/15294145.2003.10773427, p. 215)
} 
Following the publication of Descartes' Error, about 100 reviews of it were published, one of which, by Ian McGilchrist, roundly criticised the book as containing little that was new: "as Bertrand Russell commented 'Socrates used to meditate all day in the snow, but Descartes' mind only worked when he was warm.' Could there be a better illustration of the intimate relation between mental and physical existence which Descartes' philosophy was at pains to deny?" - implying that Russell, many years previously, had preempted Damasio by presenting the same argument. ${ }^{4}$ McGilchrist, an eminent psychiatrist, neuroimaging researcher, and Oxford University teacher of English, who was to go on in 2009 to publish his own magisterial book The Master and His Emissary: The Divided Brain and the Making of the Modern World, could not be ignored and Damasio issued a strong rebuttal. ${ }^{5}$ In his Reply to McGilchrist, Damasio noted that "hardly a paragraph goes by without revealing some misprision of the text and producing some misrepresentation of my words" and that "McG seeks to devalue my proposals by implying that the essence of my ideas has been in the minds of some poets and philosophers for centuries". 6 Perhaps Damasio is sensitive to the possibility of being pre-empted - or, more likely, he is attempting to unify ancient poetry and philosophy with modern-day science: "I make clear throughout the book when I refer to Aristotle, or Pascal, or Hume, my goal is to allow scientific evidence to test the poetic idea and perhaps make it more acceptable if it can be empirically supported. What a pity McG overlooked this."7

As famous as Damasio may now be, he is not yet as famous as his 19th century philosopher predecessor Friedrich Nietzsche. Richard Schacht describes Nietzsche as "one of the inaugurators of what has come to be known as Lebensphilosophie, and a progenitor of

\footnotetext{
${ }^{4}$ Iain McGilchrist, 'Book Review: Damasio, A.R. (1994) Descartes' Error' in Cognitive Neuropsychiatry, Vol. 1, Issue 2, May 1996, pp. 171-180.

${ }^{5}$ Iain McGilchrist, The Master and His Emissary: The Divided Brain and the Making of the Modern World. New Haven, CT: Yale University Press, 2009, quoted in Philip Guddemi, A Review of "The Master and His Emissary: The Divided Brain and the Making of the Modern World", World Futures, 68:8, 628-633, 2008, DOI: $10.1080 / 02604027.2012 .730427$

${ }^{6}$ Antonio R. Damasio, 'A Reply to McGilchrist's Review of Descartes' Error', in Cognitive Neuropsychiatry, Vol. 1 Issue 2, May 1996, p181-184.

${ }^{7}$ Damasio, Reply to McGilchrist, pp. 183-4.
} 
the 'philosophical anthropology' which developed out of it in Central Europe in the second quarter of this century". ${ }^{8,9}$ Schacht goes on to explain:

Philosophers $[\ldots]$ have learned to overcome both their longstanding indifference, disdain or mistrust, and also their alternative awe and obeisance, toward the natural and human sciences. And Nietzsche stands available to us as one who has a good deal to say about where and how we might go on from here. ${ }^{10}$

Given this characterisation of Nietzsche's philosophy, it would not be surprising were he to discern a biological basis to culture in humans.

Our 1886 quotation by Nietzsche (above) indeed suggests that culture has biological roots. Before putting it under the microscope, however, it must be realised that the quotation exists in more than one form. Nietzsche wrote in German and our English translation is relatively recent. However there have been many translations, some widely read and others less so (see Appendix). In spite of this, it is a commonly-held opinion that no English translation is adequate to the task of presenting Nietzsche to the English-speaking world. In the view of Richard Schacht, "no one has loomed larger in Nietzsche's English-language translation history (and interpretation history) than Walter Kaufmann". ${ }^{11}$ His translation of our quotation is also included in the Appendix. When focusing on what Nietzsche was saying, each of these and their differences have to be borne in mind, otherwise the question of Damasio's seeming pre-emption by Nietzsche may not be clearly answered.

\footnotetext{
${ }^{8}$ Richard Schacht is a Professor Emeritus of the University of Illinois and noted Nietzsche expert. His importance to the field of Nietzsche studies is demonstrated by the following article: Clark, Maudemarie. 'Richard Schacht's Nietzsche”, Journal of Nietzsche Studies 46, no. 2 (2015): 177-85. Accessed November 28, 2020. doi:10.5325/jnietstud.46.2.0177.

${ }^{9}$ Richard Schacht, 'Nietzsche' in Great Philosophers, ed. Ted Honderich, Taylor \& Francis Group, 1985. ProQuest Ebook Central, http://ebookcentral.proquest.com/lib/vuw/detail.action?docID=169127. Created from vuw on 2020-11-27 17:58:31, p. 531.

${ }^{10}$ Richard Schacht, Nietzsche, pp. 532-3.

${ }^{11}$ Richard Schacht, 'Translating Nietzsche: The Case of Kaufmann', The Journal of Nietzsche Studies, Vol. 43, Number 1, Spring 2002, pp. 68-86. Downloaded https://muse.jhu.edu/article/471527
} 


\section{Antonio Damasio and the emergence of The Strange Order of Things}

Where did Damasio's argument come from? His first book, Descartes' Error, arose out of insights gained from research into patients with brain lesions that disrupted the normal neural connections between sites in the brain that process emotions and the 'neocortical', more recently evolved sites of social reasoning predominantly in the frontal cortex. The key insight that emerged from these studies was that following such brain damage, both emotional flattening and defective reasoning occurred: the two symptoms were never dissociated and always occurred together. At the same time, Damasio discovered a distinction between what he called primary and secondary emotions. The former are phylogenetically ancient and located deep in the brain substance, in the limbic system. They include feelings such as fear, elation and disgust, seemingly hardwired and associated with predictable bodily responses such as sweating and tachycardia. On the other hand, secondary emotions are learned, variable and nuanced. Although they are located in the later-evolved frontal cortex, they still utilise the pathways and neural connections of the older primary circuitry. Damasio explains these secondary emotions create responses such as judging or reasoning, which are just as crucial to survival and flourishing as are responses to the older primary emotions. This insight begins to reveal the link between body and mind, particularly when memories ("images") of feelings are associated with particular physiological states of the body. So when a certain feeling (emotion) is perceived, the associated physiological state is evoked and decisions or judgements can be made in response to the feeling. Damasio calls this the "somatic marker hypothesis" - a name for somato-sensory feedback - and is fundamental to his growing theories about the essential part played by the body within the "circuitry of thought and judgement". 12

Where does Descartes come in, and what is his "error"? As neatly summarised by Ghasemi et al., Decartes "started the modern debate on consciousness", bringing up to date Plato's idea of the mind as the "reasoning part of the soul, involving thinking", one half of a dual system of mind and body. ${ }^{13}$ From Plato via St Augustine, this idea of dualism, of an

\footnotetext{
${ }^{12}$ Kenneth Lakritz, 'Antonio Damasio's Descartes' Error: Emotion, Reason, and the Human Brain ', Psychiatric Times, Vol. 26, Issue 12, December 2009, p. 69. Gale Academic OneFile, https://link.gale.com/apps/doc/A218450463/AONE?u=vuw\&sid=AONE\&xid=0060ec87. Accessed 22 Nov. 2020.

${ }^{13}$ Parvin Ghasemi, Samira Sasani and Jafar Abbaszadeh, 'Mrs. Dalloway: Consciousness, "Social Homeostasis," and Marxism’, Forum for World Literature Studies (Vol. 9, Issue 4), 2017, p. 666.
} 
immortal soul which encompassed the emotions, the will, the appetites and reasoning, "dominated Christian thought until the time of Descartes in the seventeenth century."14

Descartes refined the concept of dualism by restricting the concept of the immortal soul to the mind, or reasoning, rejecting perception, emotion, nutrition, growth and reproduction, as neither parts of the soul (Plato) nor functions of the soul (Aristotle), but "essentially physiological functions of the body". ${ }^{15}$ So, consciousness (Plato's concept of the mind, or the reasoning part of the immortal soul, re-defined by Descartes) now constitutes the thing that "receives sensations, or acts on the world, through a body that is an elaborate physiological mechanism." 16 As Descartes summed it up: "cogito ergo sum" - I think, therefore I am. In other words, the cogito is what thinks, and the body and material world are what is thought about (res cogitans). Here, then lies the "error": as we will see, the concept of "dualism" does not survive Damasio's argument. According to Damasio, what the body feels is just as important as what the mind thinks, and the two are inextricably entwined into one.

Five years after Descartes' Error, Damasio published The Feeling of What Happens in which, based on his neuroscientific research, he carefully describes his own emerging theory of consciousness: "Being conscious goes beyond being awake and attentive: it requires an inner self in the act of knowing". ${ }^{17}$ Consciousness is the knowing of feeling. Damasio's theories are supported by neurological and neuroanatomical arguments which reveal a notion of consciousness that arises when organisms have "malleable mental representations of their own bodies and emotions". ${ }^{18}$ Our mind notices the body's reaction to the world and responds to that experience: without our bodies there can be no consciousness.

The next important step towards The Strange Order of Things was Damasio's next book, Looking For Spinoza, which was "written in continuity with Feeling of What Happens, not quite in the same breath but certainly as an extension of the same set of facts and interpretations". ${ }^{19}$ A seventeenth century Jew from Amsterdam - and one-time pupil of Descartes - Spinoza was excommunicated from Amsterdam's Jewish community and later

\footnotetext{
${ }^{14}$ Maxwell Bennett, Virginia Woolf and Neuropsychiatry. New York: Springer, 2013, p. 200.

${ }^{15}$ Bennett, Virginia Woolf, p. 200.

${ }^{16}$ Bennett, Virginia Woolf, p. 200.

${ }^{17}$ Antonio R. Damasio, The Feeling of What Happens, London: Heinemann, 2000, p. 250.

${ }^{18}$ R. W. Kentridge, 'Review: The Feeling of What Happens: Body, Emotion and the Making of Consciousness' in Perception. 2000;29(11):1397-1398. doi:10.1068/p2911rvw

${ }^{19}$ Antonio R. Damasio, Looking for Spinoza: Joy, Sorrow and the Feeling Brain, London, Heinemann, 2003. Antonio R. Damasio, Spinoza's Monism and the Idea of the Body: A reply to Heidi Ravven in Jaak Panksepp, Antonio Damasio \& Heidi M. Ravven, 'Book Reviews', Neuropsychoanalysis, 5:2, 2008, 201-230, DOI: 10.1080/15294145.2003.10773427, p. 229.
} 
banned by religious and civil authorities in both Germany and Holland over his writings, which were seen as immoral and incorrect. ${ }^{20} \mathrm{He}$ is now "famous for being what philosophers call an "ethical naturalist" who saw himself putting the mind back into nature." 21 Among other dangerous theories, he wrote that "God and Nature are one and the same thing, therefore God is not a transcendent entity with an omniscient understanding and an allpowerful will, by whose image and likeness man has been made, and who acts in mysterious ways unbeknown by reason; that man is free not because he is gifted with a free will allowing him to choose between equally possible alternatives, but rather because he is a part of Nature that is identified with an inner strength to act and think for himself; and that the human soul is the idea of the human body, that is, the soul and the body are the same thing expressed by different attributes of God, which entails that the soul can neither survive the body as such nor be conceived individually without it". ${ }^{22}$ The last of these three theses in particular - that mind and body are of the same substance - is clearly relevant to the theory that Damasio, more than three centuries later, was to expand on. It rejects dualism, rejects Descartes' refinements, in favour of "monism". As Ravven (an eminent Spinoza scholar) elegantly explains: "He intuited that even, or perhaps especially, our ethical capacity bubbles up from the deepest layers of ourselves, our most primitive selves, rather than being a product of either God or of reason alone". 23,24

Although Spinoza's view of the "soul" is anathema to the prevailing thought at the time, and is couched in traditional philosophical language, what really concerned him is the true nature of things. He transformed the meanings of traditional concepts: rather like Damasio in the twentieth and twenty-first centuries.

The other doctrine of Spinoza's that is particularly relevant to Damasio is that of conatus, or striving, the "striving to persevere in its being", which to Spinoza is the true essence of all beings. Summarised by Ravven: "Ethics thus begins with our most basic urge for bodily survival and the maintenance and enhancement of organic integrity. It is

\footnotetext{
${ }^{20}$ Santos Campos, Andre, Spinoza : Basic Concepts, Andrews UK Ltd., 2015. ProQuest Ebook Central, http://ebookcentral.proquest.com/lib/vuw/detail.action?docID=4461381, Introduction, p. 1.

${ }^{21}$ Heidi M. Ravven, Spinoza and the Education of Desire, in Jaak Panksepp, Antonio Damasio \& Heidi M. Ravven, 'Book Reviews', Neuropsychoanalysis, 5:2, 2008, 201-230, DOI: 10.1080/15294145.2003.10773427, p. 218

${ }^{22}$ Santos Campos, Spinoza, p.2.

${ }^{23}$ For Heidi M. Ravven's cv see https://www.hamilton.edu/academics/our-faculty/directory/faculty-detail/heidiravven

${ }^{24}$ Heidi M. Ravven, Spinoza, p. 219.
} 
an overwhelming and overriding desire [...] that informs and is expressed in all our behaviour and also in all our thinking". 25

This doctrine lies behind homeostasis - explored in depth in The Strange Order of Things - and also, as Damasio speculates in Looking for Spinoza, behind the neurobiological basis of ethical behaviour. ${ }^{26} \mathrm{He}$ argues for an evolutionary basis for ethical behaviour which he relates to the principle of self-preservation, echoing an argument first made by Spinoza: "The biological reality of self-preservation leads to virtue because in our inalienable need to maintain ourselves we must, of necessity, help preserve other selves. If we fail to do so we perish and are thus violating the foundational principle, and relinquishing the virtue that lies in self-preservation". ${ }^{27}$ As Damasio puts it: "the life regulation system - homeostasis, for short - inherently embodies values in the sense that it rejects certain conditions of operation, those that would lead to disease and death, and seeks conditions that would lead to survival in optimal conditions. Homeostasis has clear preferences, likes and dislikes."28

The concept of homeostasis, originated by French physiologist Claude Bernard in 1878 , describes the ability of living organisms to control their own internal milieu, naturally and automatically, enabling them to continue living and to thrive. ${ }^{29}$ The term homeostasis, coined in 1929 by Walter Cannon, an American physiologist, comes from the Greek homeo(similar) - not from homo- (the same). This is because the optimal steady state required by living organisms of their chemical, physical, electrical milieu is within a range of values rather than having to remain the same - as happens usually with man-made systems. The organism must have a means of detecting variations in the state of the organism - such as rising or falling sodium or glucose levels, temperature, pressure, electrical charge and so on and a means of responding in a way that restores the changed state back to within the desired range.

\footnotetext{
${ }^{25}$ Heidi M. Ravven, Spinoza, p. 219.

${ }^{26}$ Spinoza's conatus principle also owes a debt to the Cartesian first law of nature: '[E]ach thing, insofar as it is in itself, always continues in the same state' (Descartes, 1985, I, 240), quoted by Valtteri Viljanen, 'Theory of Conatus' in Santo Campos, Spinoza, p. 136.

${ }^{27}$ Spinoza, quoted by Damasio, Looking For Spinoza, p. 171.

${ }^{28}$ Antonio R. Damasio, 'The Neurobiological Grounding of Human Values' in J.-P. Changeux, A. R. Damasio, W. Singer, Y. Christen (Eds.), Neurobiology of Human Values, Berlin and Heidelberg: Springer-Verlag, 2005, p. 48.

${ }^{29}$ Bernard, C., Leçons sur les phénomènes de la vie communs aux animaux et aux végétaux, Paris: J. B.

Baillières et fils, 1878 .
} 
Damasio points out that this simple, traditional view of homeostasis "provides an incomplete version of reality". ${ }^{30} \mathrm{He}$ describes two distinct kinds of control of the internal milieu parameters: the first being the traditional concept of the non-conscious form of physiological control, operating automatically "without awareness or deliberation on the part of the organism". The second kind of control mechanism which is required by numerous living creatures - by most vertebrates and certainly by humans - is a supplementary mechanism that involves feelings. ${ }^{31}$

Supplementary this system may be, it is still part of the basic system of autoregulation. Homeostatic feelings include such as thirst, hunger, desire, pleasure, well-being, malaise and certain kinds of pain. Crucially, as Damasio points out, there are two sides to homeostatic feelings. One side is likened to the standard physiological processes that regulate a raise or fall in blood glucose for example. The other side is something new: the feelings are a mental phenomenon - a direct and explicit experience. This allows the "owner" of the experience to sense the state that the organism is in. Say, for instance, an organism that depends on breathing air for supply of oxygen senses that its access to air has been cut off. This situation generates an immediate, automatic, forceful motor response aimed at getting access to air. In humans, there is a simultaneous feeling of air hunger which generates a conscious feeling of fear - this then guarantees attention to the danger the organism is facing, though it is not essential to the basic automatic motor response that kicks in.

The mental experience augments the organism's response to its changed state, strengthening its ability to return to homeostasis. Damasio describes three aspects to homeostatic feelings: content (what information the feeling carries; tachycardia or sweating for example in a feeling of anxiety), intensity (weak or strong), and valence (positive or negative). The latter is the critical aspect: feelings can be pleasant (for example joyful, energetic, enthusiastic, relaxed) or unpleasant (disagreeable, painful, sick). Altogether, feelings carry a suite of information as to whether the state of the organism is generally conducive to continued health or flourishing, or whether its state requires correction (hunger, thirst, pain, malaise for example). The consciousness of such feelings enables the owner of the organism to become a "potential agent of its own regulation". ${ }^{32}$

\footnotetext{
${ }^{30}$ Antonio Damasio, Hanna Damasio, 'Exploring the concept of homeostasis and considering its implications for economics', Journal of Economic Behavior \& Organization, Volume 126, Part B, 2016, p. 126.

${ }^{31}$ Damasio et al, Concept of Homeostasis, p. 126.

32 Damasio et al, Concept of Homeostasis, p. 126.
} 
Homeostatic feelings are channelled into the mind - they have a mental aspectwhich is also valenced, or having a positive or negative affect. The organism's owner is compelled to act on the information provided by the feeling, and depending on its intensity, and the type of affect, will react accordingly: "correct as needed", "correct urgently", "do little or nothing", or "do more of what you have been doing". Feelings are affect-full mental representations of changes to the organism's state and demand a conscious response.

For simple organisms, the automatic kind of homeostatic control is reliable and optimal for continued life. The conscious, feeling variety of regulation, however, enables the organism to become far more adaptable to a larger range of circumstances. Feelings experienced in the mind enable learning, particularly as they are imbued with positive or negative valence ("appetitive" or "aversive" conditions). However, with increased complexity comes increased risk of malfunction, the main reason being the degree of freedom of operation that comes with it. Some conscious choices of response to feelings may be in conflict or even counter to the organism's homeostatic goals. This is partly because of the engagement of "the complex machinery of affect, namely, drives, motivations and emotions." 33

Damasio, as foreshadowed by Spinoza, goes on to extend the idea of homeostasis to societies as a whole. His concept of social homeostasis, the "rules and conventions of society, [which] is the result of the biological phenomenon of consciousness - rules [which] are the extensions of the basic homeostatic arrangements at the level of society and culture". ${ }^{34}$ Therefore, sociocultural homeostasis optimizes the workings of basic homeostasis to ensure survival in a wider zone, society, and to improve the quality of life: these social conventions and rules provide the "additional layers of control [which] shape instinctual behaviour so that it can be adapted flexibly to a complex and rapidly changing environment and ensure survival for the individual and for others [my italics]". 35

David Hume, the eighteenth-century Scottish philosopher (1711-1776), is another significant predecessor of Damasio's. He was critical of philosophers, ancient and modern, who failed to base their reasoning on "fact and observation". ${ }^{36}$ He regarded such philosophers, writing under a "smokescreen of metaphysics" as promoting "religious fears and prejudices" in their

\footnotetext{
${ }^{33}$ Damasio et al, Concept of Homeostasis, p. 127.

${ }^{34}$ Antonio R. Damasio, Spinoza, p. 168, quoted by Ghasemi et al., Mrs Dalloway, p. 683.

${ }^{35}$ Antonio Damasio, Decartes' Error, p. 124, quoted by Ghasemi et al., Mrs Dalloway, p. 683.

${ }^{36}$ William Edward Morris and Charlotte R. Brown, 'David Hume', The Stanford Encyclopedia of Philosophy (Summer 2020 Edition), Edward N. Zalta (ed.),

URL=<https://plato.stanford.edu/archives/sum2020/entries/hume/>.
} 
arguments for doctrines such as "the existence of God, the immortality of the soul, and the nature of God's particular providence". ${ }^{37}$ In his work he proceeded from such criticism with what he called a scientific study of human nature as a kind of mental geography or anatomy of the mind, trying to "find a set of laws that explain how the mind's contents - perceptions, as he calls them - come and go in the mind and how simple perceptions combine to form complex perceptions in ways that explain human thought, belief, feeling and action". ${ }^{38}$ This sounds very much like Damasio's mission.

Also with great similarity to Damasio's quest, Hume's project, as outlined in his Treatise of Human Nature (3.3.1), is to discover a naturalistic explanation of human morals, "to discover the true origin of morals, and of that love or hatred, which arises when we contemplate our own or other people's character traits and motives". ${ }^{39,40} \mathrm{He}$ argues in his Second Enquiry that there is a "general benevolence to human nature" and that in our morals we are motivated not on self-interest (as argued by his predecessor, Hobbes) but on what benefits society. This theory is a clear predecessor to Damasio's conclusions regarding social homeostasis. ${ }^{41}$

Before returning to Damasio and The Strange Order of things, it is important to mention one further predecessor of his: the American philosopher and psychologist, William James (18421910) - who, like Damasio, trained as a physician. James produced a new concept of the origins of emotions, central to Damasio's thesis, that ran counter to earlier philosophers, including those mentioned already: Plato, Aristotle, Spinoza, Descartes, Hobbes, and Hume. The time-honoured concept of emotions, that they consisted of "eternal and sacred psychic entities", was upturned in what became known as the James-Lange theory (because of its similarity to a theory announced by James' contemporary Carl Lange). James wrote: 'the bodily changes follow directly the PERCEPTION of the exciting [= initiating] fact, and that our feeling of the same changes as they occur IS the emotion". ${ }^{42,43}$ For example, when we

\footnotetext{
${ }^{37}$ Morris et al., David Hume. (3)

${ }^{38}$ Morris et al., David Hume. (3)

${ }^{39}$ David Hume, A Treatise of Human Nature, edited by L. A. Selby-Bigge, $2^{\text {nd }}$ ed. revised by P. H. Nidditch, Oxford: Clarendon Press, 1975, p. 575.

${ }^{40}$ Quoted by Morris et al., David Hume (7.2)

${ }^{41}$ And also a predecessor of the recent book Humankind, by Rutger Bregman (trans. Elizabeth Manton and Erica Moore, London and Oxford: Bloomsbury Publishing, 2020). In it, the author argues: "I make a new argument: that it is realistic, as well as revolutionary, to assume that people are good. The instinct to cooperate rather than compete, trust rather than distrust, has an evolutionary basis going right back to the beginning of Homo sapiens".

${ }^{42}$ William James, 'What is an Emotion', in Mind, Vol. 9, No. 34, April 1884, pp. 188-205.

${ }^{43}$ Lange, Carl Georg, Om sindsbevagelser: et psyko-fysiologisk Studie. 1885, Translated as The Emotions (along with William James “What is an Emotion?”), A. Haupt (trans.), Baltimore: Williams \& Wilkins, 1922.
} 
perceive that we are in danger, this perception directly sets off a collection of bodily responses, and our awareness of these responses is what constitutes fear. However, James' theory caused controversy as he went on to explain that following perception, the body reacts and the reaction creates the emotion: "we lose our fortune, [we] cry, and the crying makes us feel sad." ${ }^{44}$ As Scarantino et al. explain, "the counterintuitive implication that emotions do not cause their manifestations but rather emerge from them struck many as problematic, because it seemed to undermine the idea that emotions are important to us." 45 As Damasio has found, however, this sequence is indeed true: the fact is perceived by the body, the body responds ("emotion") and a conscious feeling follows. Damasio now is accumulating the evidence that James required:

"Of course the physiological question arises, how are the changes felt? - after they are produced, by the sensory nerves of the organs bringing back to the brain a report of the modifications that have occurred? or before they are produced, by our being conscious of the outgoing nerve-currents starting on their way downward towards the parts they are to excite? I believe all the evidence we have to be in favour of the former alternative". ${ }^{46}$

The Strange Order of Things commences with a discussion on homeostasis, which, as Damasio demonstrates, is the "foundation of the precursors to feeling and subjective perspective in the absence of mental processes in lower organisms", leading to the "emergence of behavioural strategies and devices capable of ensuring life maintenance and flourishing, in simple as well as complex organisms, humans included." ${ }^{47}$ Later in the book, he proceeds to explore more fully his theories on homeostasis and the biological roots of cultures:

\footnotetext{
${ }^{44}$ James, William, Emotion, p. 190.

${ }^{45}$ Putnam, Ruth Anna. "Introduction." Introduction. In The Cambridge Companion to William James, edited by Ruth Anna Putnam, 1-10. Cambridge Companions to Philosophy. Cambridge: Cambridge University Press, 1997. doi:10.1017/CCOL0521452783.001, (3)

46 James, William, Emotion, p. 193.

${ }^{47}$ Antonio R. Damasio, Strange Order of Things, III.10.
} 
In later organisms, after nervous systems emerged, minds became possible and, within them, feelings along with all the images that represented the exterior world and its relation to the organism. Such images were supported by subjectivity, memory, reasoning, and eventually verbal language and creative intelligence. The instruments and practices that constitute cultures and civilizations in the traditional sense emerged thereafter. ${ }^{48}$

Damasio puts forward convincing arguments that show the evolutionary steps along the way to the emergence of human cultures, with feelings becoming the motives for new forms of response, "engendered by the rich creative intellect and motor ability of humans". An important part of his reasoning echoes Hume's view of human societies are underpinned not by self-interest but by altruism - benevolence in human regard toward each other - or as Damasio puts it: "yearning to alleviate the suffering of others [... and] delighting in ways to improve the lives of others", while "taming the beast" of violence towards others. ${ }^{49}$ The development of religious beliefs in response to the demands of personal and social homeostasis is argued, along with the arts, philosophical enquiry and the sciences, all credited to both conscious feeling and creative intelligence. With great ingenuity Damasio convincingly connects the "biology of feelings, consciousness and the roots of the cultural mind". ${ }^{50}$ He has elegantly demonstrated how cultural experiences leave neurobiological traces.

In at least two eminent scientific journals, The Strange Order of Things has been received with admiration and only muted criticism. Adrian Woolfson, writing in Nature, feels that "a more detailed exposition of the scientific evidence supporting his assertions" was needed, while Adrian Solms in his review published in the Journal of the American Psychoanalytic Association noted: "However, just as Einstein unintentionally ushered in the era of quantum mechanics — where God plays dice with the universe - so, too, the scientific revolution introduced here by Damasio might go further than he intends". 51

\footnotetext{
${ }^{48}$ Antonio R. Damasio, Strange Order of Things, III.10.

49 Antonio R. Damasio, Strange Order of Things, III.10.

${ }^{50}$ Antonio R. Damasio, Strange Order of Things, III.13.

51 Adrian Woolfson, 'The messy biological basis of culture', in Nature, 554(7690), 2018, doi:http://dx.doi.org.helicon.vuw.ac.nz/10.1038/d41586-018-01326-5. p.30. Solms, Mark. "Book Review: The Strange Order of Things: Life, Feeling, and the Making of Cultures', Journal of the American Psychoanalytic Association, 66, no. 3 (June 2018): https://doi.org/10.1177/0003065118780182, pp. 579-86.
} 


\section{Nietzsche and Beyond Good and Evil}

The author of the first of our two quotations, German philosopher, psychologist, and classical philologist Friedrich Wilhelm Nietzsche, wrote Beyond Good and Evil (BGE) late in his career. ${ }^{52}$ The book followed what he considered his masterpiece, Thus Spoke Zarathustra and was addressed “to his contemporaries, in his favourite role of an 'untimely man', telling them things about themselves that he is sure they would rather not hear". ${ }^{53}$ It was a "critique of modernity" in which he warned of the hastening degeneration of German culture, just as that of the Ancient Greeks had become decadent with the advent of Euripides and Socrates. As Tanner explains, from Nietzsche's point of view, the Greeks' ‘tragic heroism' succumbed to the optimistic rationalism of these latter philosophers who taught the virtue of knowledge, thus depriving their culture of their "greatest insight": the more we know about reality, the more frightful we realise it is. Later on, though, Nietzsche denies the urge for knowledge and instead describes our basic urge as the 'will to power'. Our quotation, however, concerns culture.

Culture is Nietzsche's overriding concern, and how culture imposes our values on us. We feel that it is the world in general that is doing the imposing, and going against the grain of one's culture is extremely difficult. To do so requires superhuman strength, needing such an enormous act of will that a person who could successfully overcome the decadence of their culture would constitute a new species (an übermensch). But a philosopher, a "superior human being", needs to step aside from the shared values of society so as to be able to examine and understand them. The other constraint faced by a philosopher is, as our quotation sets out, the difference in tempo between the language in which he writes and the pace of his thought. Nietzsche describes German language as 'slow and ponderous' but his thinking as full of the speed and ease that is natural to speakers of the southern Mediterranean languages. This difference in tempo Nietzsche ascribes to "Stoffwechsels" - metabolism. He appears to be creating a link between physical, biological processes and language or culture.

\footnotetext{
${ }^{52}$ Nietzsche scholar Richard Schacht discusses the characterisation of Nietzsche with regard to the description of him by Walter Kaufmann, the Nietzsche translator and interpreter who played an important part in bringing Nietzsche to the attention of the English-speaking world in the 1950s and 60s. See Richard Schacht, 'Translating Nietzsche: The Case of Kaufmann' in Journal of Nietzsche Studies, Vol. 43, no. 1, 2012, p. 69. ${ }^{53}$ Michael Tanner, 'Introduction' in Friedrich Wilhelm Nietzsche, Beyond Good and Evil, trans. R. J. Hollingdale, London: Penguin Books, 1990, p. 7
} 
First, the context of Nietzsche's quotation needs to be understood. What he wrote was radical and although $B G E$ was little read following its publication, it entered the "bloodstream of western cultural life" in the early 1900s and Nietzsche became a "cultural cause-célèbre" ${ }^{54}$ Beards places Nietzsche within several philosophical traditions: postKantian German idealism, the Enlightenment campaign against the superstition of religion, and late Romanticism, "a movement which promoted aesthetics and artistic creativity as a counter to life increasingly controlled and suffocated by industrial and economic forces, a desire for something more than the bourgeois values of the increasingly post-Christian modern West". ${ }^{55}$ Rejecting Christianity, Nietzsche turned instead to pre-Christian cultural values, on which he was an expert, being a professor of Classical philology.

Aristotle, as well as Nietzsche, believed that virtues can be regarded as "ethical habits conducive to the flourishing of the human good" and that from human nature arises "the seeking of truth, the pursuit of moral good, life and health, friendship and the justice and fairness required for the proper unfolding of human existence which is essentially social in nature". ${ }^{56}$ This statement fits well with what Damasio, much later, has argued. However, when thinking about the course of evolution of human society, Nietzsche draws on Hegel's view that "there may be something operative in the history of human thought which is not available to the consciousness of the individuals within that history; that somehow individual thinking is blind to the forces that truly motivate and control it." ${ }^{57}$ Nietzsche aims to establish the true foundations of morality, which he believes have been merely assumed (rather than proven) by previous philosophers. However, in saying that he ought to find out the correct basis of morality, he implies a task that "is itself a true and valid aspect of morality". ${ }^{58} \mathrm{He}$ arrives at the conclusion that true morality is that which promotes the survival of the species.

Nietzsche thence comes to believe that, for survival of human society, what is required is the reassertion of power by a dominant, noble elite, rejecting the socialist - and Christian - view which he regards as the greatest threat to human survival. In $B G E$ he goes on to detail the rights and responsibilities of the noble class and the rest ('the herd'), whose main responsibility is to support the nobles. One wonders here about the influence on Nietzsche of the writing of Machiavelli - one of his heroes - especially his book Il Principe

\footnotetext{
${ }^{54}$ Andrew Beards, 'Beyond Nietzsche's Beyond Good and Evil', The Downside Review, 2005;123(430), doi:10.1177/001258060512343004, p. 45.

55 Beards, 'Beyond Nietzsche', p. 47.

56 Beards, 'Beyond Nietzsche', p. 65.

${ }^{57}$ Beards, 'Beyond Nietzsche', p. 46.

58 Beards, 'Beyond Nietzsche', p. 50.
} 
(1513). ${ }^{59}$ Both agreed with the principle of 'the ends justify the means', the ends being to keep power in the hands of those to whom it rightly belongs, the noble class: according to Dombowsky, for Nietzsche, morality is reduced to politics. ${ }^{60}$ Then, with a degree of contradiction to what he wrote elsewhere, Nietzsche, like his $17^{\text {th }}$ century predecessor Thomas Hobbes, rejects 'love of neighbour' as an arbitrary basis of society, in favour of 'fear of neighbour' being what really motivates human beings and social action. ${ }^{61}$

There was, of course, something else that Nietzsche admired in Machiavelli: his vivacious, presto style of writing. This brings us back to our quotation: tempo was important to Nietzsche - how does this apply to humans? What did he mean by character of the race? - is Nietzsche's meaning conveyed correctly by the translation? Our translators (see Appendix) agree on the best word choices for these three things, but, although the published translations of the quotations as a whole are very similar, there are some crucial differences, most importantly with the word Stoffwechsels. As Schacht argues, translators' choices "can have unfortunate consequences for the way Nietzsche comes across and is understood" and the two equivalents we have for this word may be an example of this. ${ }^{62}$

The two different translations for Stoffwechsels in our quotations are assimilation of nutriment (Zimmern) and metabolism (the others). The inverted commas have been either retained or dispensed with. The Cambridge Dictionary gives only metabolism, as does Collins, Langenscheidt and many other on-line dictionaries. Interestingly, assimilation of nutriment is the equivalent chosen by the first English translator of the work, Helen Zimmern, a woman born in Germany who became a naturalised Briton: she befriended Nietzsche when in Switzerland in the mid 1880s - he referred to her as 'extremely clever'. ${ }^{63}$ But even though she had personal knowledge of Nietzsche, can we rely on her translation? - a later translator, Marion Faber, wrote of her: "Although often resourceful and generally accurate, her translation contains numerous inaccuracies and a number of bowdlerisations. In Aphorism

\footnotetext{
${ }^{59}$ D. Dombowsky, 'Nietzsche and Machiavellism', in Nietzsche's Machiavellian Politics, London: Palgrave Macmillan, 2004, https://doi.org/10.1057/9780230000650_5.

${ }^{60}$ D. Dombowsky, 'Wills to Power, Genealogy: Which Ones are at War?', in Nietzsche's Machiavellian Politics, p. 10.

61 "After all, "love to our neighbour" is always a secondary matter, partly conventional and arbitrarily manifested in relation to our FEAR OF OUR NEIGHBOUR. After the fabric of society seems on the whole established and secured against external dangers, it is this fear of our neighbour which again creates new perspectives of moral valuation." Friedrich Wilhelm Nietzsche, Beyond Good and Evil, trans. Helen Zimmern, Section 201, Project Gutenberg, release date December 7, 2009, www.gutenberg.org Ebook \#4363.

${ }^{62}$ Richard Schacht, Translating Nietzsche, p. 78.

${ }^{63}$ Creffield, C. A., 'Zimmern, Helen, Oxford Dictionary of National Biography, 2004, https://doiorg.helicon.vuw.ac.nz/10.1093/ref:odnb/55284
} 
144, for example, Zimmern has Nietzsche speaking of Jesus's 'idea' that he was the son of God, where 'fantasy' would have been a more accurate translation". ${ }^{64}$

But 'nutriment' was an important topic for Nietzsche, and his concept of 'metabolism' may not coincide exactly with our concept of it in the late $20^{\text {th }}$ or $21^{\text {st }}$ centuries. Health generally was a significant criterion in Nietzsche's valuation of practices and attitudes in the life of individuals and cultures: unhealthy individuals or cultures were 'weak' or 'decadent'. Furthermore, to "live with health, strength and vital force denotes the ability to give oneself over to self-transformation - a process Nietzsche equates with healthy digestion [italics mine]". ${ }^{65}$ Nietzsche himself had frequent illnesses, often characterised as digestive or stomach problems, and usually turned to physicians who took this view, such as a quack in a Bayreuth clinic who prescribed cold-water enemas first thing every morning and four small meals a day composed almost entirely of meat. ${ }^{66}$ Generally, "moral and psychological health are taken as the good effects of physiological well-being that has its root in the processes of alimentation and digestion". ${ }^{67}$

So, virtue resides in good health, and good health requires good digestion - or metabolism. As confirmed in his last work, the semi-autobiographical Ecce Homo, unhealthiness is marked by decadence and decay, an inability to digest properly (dyspepsia), or an inability to convert what is digested into an intellectual or cultural transformation. ${ }^{68}$ In Untimely Meditations, Nietzsche pictures the absorption of culture thus:

Cultural sensibility then lies quietly within, like a snake that has swallowed rabbits whole and now lies in the sun and avoids all unnecessary movement. The inner process is now the thing itself, is what actually constitutes 'culture'. Anyone observing this has only one wish, that such a culture should not perish of indigestion. ${ }^{69}$

\footnotetext{
${ }^{64}$ M. Faber, 'Introduction', in F. Nietzsche, Human, all too human (1984), p. xxv

${ }^{65}$ Robert T. Valgenti, 'Nietzsche and Food' in D. M. Kaplan (ed.), Encyclopedia of Food and Agricultural Ethics, Springer Nature B.V. 2019, https://doi.org/10.1007/978-94-024-1179-9

${ }^{66}$ Young, Julian. "Auf Wiedersehen Bayreuth." Chapter. In Friedrich Nietzsche: A Philosophical Biography, Cambridge: Cambridge University Press, 2010. doi:10.1017/CBO9781139107013.012. pp.201-28.

${ }^{67}$ Valgenti, Nietzsche and Food, 'Introduction'.

${ }^{68}$ Nietzsche, Friedrich Wilhelm, The Anti-Christ, Ecce homo, Twilight of the idols, and other writings, New York: Cambridge University Press, 2005.

${ }^{69}$ Nietzsche, Friedrich Wilhelm, Untimely Meditations. E-book, Cambridge [U.K.]: Cambridge University Press, 1997, https://hdl.handle.net/2027/heb.08912, pp. 78-9
} 
Referring to the "boorish" German taste, arts and manners he uses a similar metaphor:

He digests his events badly; he never gets 'done' with them; and German depth is often only a difficult, hesitating 'digestion'. And just as all chronic invalids, all dyspeptics like what is convenient, so the German loves 'frankness' and 'honesty'. ${ }^{70}$

If an individual wishes to be a "free spirit", a philosopher escaping the herd mentality, able to view life from a distance, again Nietzsche gives advice couched in gastric terms:

If one wishes to be a free spirit able to undergo a transformation, one must protect the stomach by eating what is best and not what is most available: "their spirit is a ruined stomach: it recommends death! Because truly, my brothers, the spirit is a stomach!"71

It seems that we are getting closer to Damasio. 'Food' comes from our external environment, and by 'metabolism' is absorbed and becomes part of the substance of our body. 'Culture', likewise, is absorbed into us and is metabolised into the substance of our being. Digestion - metabolism - is now an embodiment of the spirit. The mind-body distinction is becoming undermined. The "process of interpretation is reduced to neither pure cognition nor pure physiology, illustrating how to digest and metabolise the very distinction between body and mind and nature and culture." 72

As mentioned, there seems to be agreement amongst our translators on the other key words in our Nietzsche quotation. Borrowed from the Italian, tempo in English means speed or pace, but tempo does not have any connotation of rapidity which often speed or pace have. In the interesting discussion of tempo and culture in BGE Section 28 (Appendix Two), Nietzsche applies to mental processes (thought), physical processes (digestion, running, breathing), and cultural elements (language, humour, music, writing) a tempo that he asserts is characteristic of a particular race. To move at a tempo in mental, physical and cultural processes that is presto or allegrissimo (fast, very cheerful) is to be healthy, free-spirited, emancipated, lively and merry - like the Italians, Greeks, and French men like Voltaire and Diderot. On the other hand, Germans, suffering from a tempo that is neither presto nor allegrissimo are ponderous, pompously clumsy, long-winded and unable to manage the cultures of the Italians and Greeks

\footnotetext{
${ }^{70}$ Friedrich Nietzsche, Beyond Good and Evil: Prelude to a Philosophy of the Future, trans. Judith Norman, Cambridge: Cambridge University Press, 2002, p. 282

${ }^{71}$ Nietzsche, F. W., Thus Spoke Zarathustra, trans: Del Caro, A. P., \& Pippin, R. B., New York: Cambridge University Press, 2006.

${ }^{72}$ Valgenti, Nietzsche and Food, 'How to Become What You Eat'
} 
(which are typified by the "buffoon and the satyr") either physically, mentally or philosophically.

Nietzsche is conflating mind, body and culture with his concept of tempo. He goes on to assign to "races" each a particular tempo, and because of his unitary view of mind, body and culture, it is likely that what he means by race is a classification of humans based on physical characteristics (such as skin colour, facial form or eye shape) as well as by common descent or place of origin. It is less likely that he means by race what today we would refer to as ethnicity, a group that shares a distinctive culture, religion or background. Given his view that tempo is a common feature - character - of members of a particular race, and that it encompasses the mental, physical and cultural, we now see that his concept could be approaching that which Damasio calls homeostasis, the life-regulation system.

\section{Did Nietzsche pre-empt Damasio?}

Given the above, I think our Nietzsche quotation can be interpreted as saying:

When one tries to understand another culture [render from one language to another], no matter how hard one tries, it is impossible [honestly meant translations become vulgarisations]. The reason is that one's innate tempo, the essence of one's own culture, inevitably differs from the tempo of the other. The tempo is of both the mind and the body and is absorbed from the culture of our surroundings, and becomes part of us.

Or, put more simply:

Culture is a creation of, and resides in, the body's metabolism and the mind. There is a natural force, tempo, which is its foundation and source.

As for Damasio's quotation, in the light of the earlier discussion, I can restate it as follows:

There are three crucial mental faculties required for creative intelligence [in humans] and they are the ability to make images, affect, and consciousness. These mental 
faculties are the creation of, and reside in the body's substance and metabolism. There is a natural force, homeostasis, which is their foundation and source.

I think Nietzsche got it right. Damasio has convincingly proven, by scientific research and thinking, the argument that Nietzsche proposed through thinking and reason alone. So yes, we can say that Damasio was pre-empted, but it is also true to say that what he has established was the culmination of a long line of philosophical argument dating back to the ancient Greeks. Nietzsche also inherited those same centuries of philosophical thought and for him, too, they formed the springboard for his original thinking. As Damasio himself admits, "One of the values of philosophy is that throughout its history it has prefigured science. In turn, I believe, science is well served by recognising that historical effort." 73 Translation and interpretation are inextricable parts of this story. The works of the earlier generations of philosophers needed to be read and understood by both Nietzsche and Damasio, and as we have seen, whenever one reads a translation, there is always the risk of the original text - or the thinking of the writer of the original text - being misinterpreted or misunderstood in some way. The added complication, as I have demonstrated and as Schacht showed so comprehensively, is the difficulty of understanding and translating Nietzsche himself.

As Nietzsche believed, we are never going to get it right, but I hope this interpretation of both him and of Damasio has not been excessively vulgarised.

\footnotetext{
${ }^{73}$ Antonio R. Damasio, Looking for Spinoza, p. 15
} 


\section{Bibliography}

\section{References: Damasio}

Damasio, Antonio R., 'A Reply to McGilchrist's Review of Descartes' Error', in Cognitive Neuropsychiatry, Vol. 1 Issue 2, May 1996

Damasio, Antonio R., Decartes' Error: Emotion, Reason, and the Human Brain, New York: Grosset-Putnam, 1994.

Damasio, Antonio R., 'Descartes Error Revisited', Journal of the History of the Neurosciences, 2001, 10:2.

Damasio, Antonio R., Looking for Spinoza : joy, sorrow, and the feeling brain, London:

Heinemann, 2003.

Damasio, Antonio R., Spinoza's Monism and the Idea of the Body: A reply to Heidi Ravven in Panksepp, Jaak, Antonio Damasio \& Heidi M. Ravven, 'Book Reviews', Neuropsychoanalysis, 5:2, 2008, 201-230, DOI: 10.1080/15294145.2003.10773427

Damasio, Antonio R., The Strange Order of Things: Life, feeling and the making of cultures, New York: Pantheon, 2018.

Damasio, Antonio R., The Feeling of What Happens, London: Heinemann, 2000

Damasio, Antonio R., 'The Neurobiological Grounding of Human Values' in J.-P. Changeux, A. R. Damasio, W. Singer, Y. Christen (Eds.), Neurobiology of Human Values, Berlin and Heidelberg: Springer-Verlag, 2005

Damasio, Antonio R., Transparent Feelings: A reply to Jaak Panksepp and Douglas Watt, in Jaak Panksepp, Antonio Damasio \& Heidi M. Ravven, 'Book Reviews', Neuropsychoanalysis, 5:2, 2008, 201-230, DOI: 10.1080/15294145.2003.10773427

Damasio, Antonio, Hanna Damasio, 'Exploring the concept of homeostasis and considering its implications for economics', Journal of Economic Behavior \& Organization, Volume 126, Part B, 2016.

Douglas, Alexander, 'The Affects' in Santos Campos, Spinoza.

Ghasemi, Parvin, Samira Sasani and Jafar Abbaszadeh, 'Mrs. Dalloway: Consciousness, "Social Homeostasis," and Marxism', Forum for World Literature Studies (Vol. 9, Issue 4), 2017.

Gluck, Andrew L., Damasio's Error and Descartes' Vision, Scranton and London: Scranton University Press, 2007.

Hume, David, A Treatise of Human Nature, edited by L. A. Selby-Bigge, $2^{\text {nd }}$ ed. revised by P. H. Nidditch, Oxford: Clarendon Press, 1975.

James, William, 'What is an Emotion', in Mind, Vol. 9, No. 34, April 1884

Kentridge R. W., 'Review: The Feeling of What Happens: Body, Emotion and the Making of Consciousness', Perception, 2000;29(11):1397-1398. doi:10.1068/p2911rvw

Lakritz, Kenneth, 'Antonio Damasio's Descartes' Error: Emotion, Reason, and the Human Brain ', Psychiatric Times, Vol. 26, Issue 12, December 2009, p. 69. Gale Academic OneFile, https://link.gale.com/apps/doc/A218450463/AONE?u=vuw\&sid=AONE\&xid=0060e c87. 
Lange, Carl Georg, Om sindsbevagelser: et psyko-fysiologisk Studie. 1885, Translated as The Emotions (along with William James "What is an Emotion?"), A. Haupt (trans.), Baltimore: Williams \& Wilkins, 1922.

Morris, William Edward and Charlotte R. Brown, 'David Hume', The Stanford Encyclopedia of Philosophy (Summer 2020 Edition), Edward N. Zalta (ed.), URL $=<$ https://plato.stanford.edu/archives/sum2020/entries/hume/>.

McGilchrist, Iain, 'Book Review: Damasio, A.R. (1994) Descartes' Error' in Cognitive Neuropsychiatry, Vol. 1, Issue 2, May 1996

Ravven, Heidi M., Spinoza and the Education of Desire, in Jaak Panksepp, Antonio Damasio \& Heidi M. Ravven, 'Book Reviews', Neuropsychoanalysis, 5:2, 2008, 201-230, DOI: $10.1080 / 15294145.2003 .10773427$

Santos Campos, Andre (ed.), Spinoza: Basic Concepts, digital version, Andrews UK Ltd, www.andrewsuk.com. Downloaded from http://ebookcentral.proquest.com/lib/vuw/detail.action?docID=4461381

Scarantino, Andrea and Ronald de Sousa, "Emotion", The Stanford Encyclopedia of Philosophy (Winter 2018 Edition), Edward N. Zalta (ed.), URL = <https://plato.stanford.edu/archives/win2018/entries/emotion/>.

Solms, Mark. 'Book Review: The Strange Order of Things: Life, Feeling, and the Making of Cultures', Journal of the American Psychoanalytic Association, 66, no. 3 (June 2018):

Viljanen, Valtteri, 'Theory of Conatus' in Santos Campos, Spinoza, p. 135.

Woolfson, Adrian, 'The messy biological basis of culture', in Nature, 554(7690), 2018, doi:http://dx.doi.org.helicon.vuw.ac.nz/10.1038/d41586-018-01326-5

\section{References: Nietzsche}

Beards, Andrew, 'Beyond Nietzsche's Beyond Good and Evil', The Downside Review, 2005;123(430).

Bennett, Maxwell. Virginia Woolf and Neuropsychiatry. New York: Springer, 2013.

Creffield, C. A., 'Zimmern, Helen, Oxford Dictionary of National Biography, 2004, https://doi-org.helicon.vuw.ac.nz/10.1093/ref:odnb/55284

Dombowsky, D., 'Nietzsche and Machiavellism', in Nietzsche's Machiavellian Politics, London: Palgrave Macmillan, 2004, https://doi.org/10.1057/9780230000650_5.

Dombowsky, D, 'Wills to Power, Genealogy: Which Ones are at War?', in Nietzsche's Machiavellian Politics, London: Palgrave Macmillan, 2004, https://doi.org/10.1057/9780230000650_5.

Faber, M., 'Introduction', in F. Nietzsche, Human, all too human (1984), p. xxv

Nietzsche, Friedrich Wilhelm, Beyond Good and Evil, trans. Helen Zimmern, Project Gutenberg eBook 2009.

Nietzsche, Friedrich Wilhelm, Beyond Good and Evil, trans. R. J. Hollingdale, London: Penguin Books, 1973, 1990

Nietzsche, Friedrich Wilhelm, The Anti-Christ, Ecce homo, Twilight of the idols, and other writings, New York: Cambridge University Press, 2005. 
Nietzsche, F. W., Thus Spoke Zarathustra, trans: Del Caro, A. P., \& Pippin, R. B., New York: Cambridge University Press, 2006.

Nietzsche, Friedrich Wilhelm, Untimely Meditations. E-book, Cambridge [U.K.]: Cambridge University Press, 1997, https://hdl.handle.net/2027/heb.08912

Schacht, Richard, 'Nietzsche' in Great Philosophers, ed. Ted Honderich, Taylor \& Francis Group, 1985. ProQuest Ebook Central, http://ebookcentral.proquest.com/lib/vuw/detail.action?docID=169127.

Schacht, Richard, 'Translating Nietzsche: The Case of Kaufmann', The Journal of Nietzsche Studies, Vol. 43, Number 1, Spring 2002. https://doi.org/10.1177/0003065118780182 Southwell, Gareth. A Beginner's Guide to Nietzsche's Beyond Good and Evil, John Wiley \& Sons, Incorporated, 2008. ProQuest Ebook Central, https://ebookcentral-proquestcom.helicon.vuw.ac.nz/lib/vuw/detail.action?docID=437548.

Valgenti, Robert T., 'Nietzsche and Food' in D. M. Kaplan (ed.), Encyclopedia of Food and Agricultural Ethics, Springer Nature B.V. 2019, https://doi.org/10.1007/978-94-0241179-9

Young, Julian. "Auf Wiedersehen Bayreuth." Chapter. In Friedrich Nietzsche: A Philosophical Biography, Cambridge: Cambridge University Press, 2010. doi:10.1017/CBO9781139107013.012. 


\section{Appendix One}

Friedrich Nietzsche, Beyond Good and Evil, Ch. 2, Section 28, 1886.

"Was sich am schlechtesten aus einer Sprache in die andere übersetzen lässt, ist das tempo ihres Stils: als welcher im Charakter der Rasse seinen Grund hat, physiologischer gesprochen, im Durchschnitts-tempo ihres "Stoffwechsels". Es giebt ehrlich gemeinte Übersetzungen, die beinahe Fälschungen sind, als unfreiwillige Vergemeinerungen des Originals, bloss weil sein tapferes und lustiges tempo nicht mit übersetzt werden konnte, welches über alles Gefährliche in Dingen und Worten wegspringt, weghilft."

Friedrich Wilhelm Nietzsche, Jenseits von Gut und Bose, Project Gutenberg EBook, January, 2005 [EBook \#7204]

1. "What is most difficult to render from one language into another is the TEMPO of its style, which has its basis in the character of the race, or to speak more physiologically, in the average TEMPO of the assimilation of its nutriment. There are honestly meant translations, which, as involuntary vulgarizations, are almost falsifications of the original, merely because its lively and merry TEMPO (which overleaps and obviates all dangers in word and expression) could not also be rendered."

trans. Helen Zimmern, 1906, Project Gutenberg Ebook: Release Date: December 7, 2009 [EBook \#4363]

2. "What is most difficult to render from one language into another is the tempo of its style, which has as its basis the character of the race, or to speak more physiologically, in the average tempo of its metabolism. There are honestly meant translations that, as involuntary vulgarizations, are almost falsifications of the original, merely because its bold and merry tempo (which leaps over and obviates all danger in things and words) cannot be translated."

trans. Walter Kaufmann, New York: Random House, 1966, p. 28.

3. "That which translates worst from one language to another is the tempo of its style, which has its origin in the character of the race, or, expressed more physiologically, in the average tempo of its 'metabolism'. There are honestly mean translations, which as involuntary vulgarisations of the original, are almost falsifications simply because it was not possible to translate also its brave and happy tempo, which leaps over and puts all that is perilous in things and words."

trans. R. J. Hollingdale, London: Penguin Books, 1990, p. 45. 
4. "The hardest thing to translate from one language to another is the tempo of its style; this style has as its basis the character of the race, or to speak more physiologically, in the average tempo of the race's 'metabolism'. There are some well-intended translations that are almost counterfeits, involuntary crudifications of the original, simply because they could not capture its bright, brave tempo, one that leaps over, transports over all the dangers in words and things."

Friedrich Nietzsche, Beyond Good and Evil: Prelude to a Philosophy of the Future, trans. Marion Faber, Oxford: Oxford University Press, February 25, 1999, p. 29.

5. "The hardest thing to translate from one language into another is the tempo of its style, which is grounded in the character of the race, or - to be more physiological - in the average tempo of its "metabolism". There are wellmeaning interpretations that are practically falsifications, they involuntarily debase the original, simply because it has a tempo that cannot be translated, a tempo that is brave and cheerful and leaps over every danger in things and in words."

Friedrich Nietzsche, Beyond Good and Evil: Prelude to a Philosophy of the Future, trans. Judith Norman, Cambridge: Cambridge University Press, 2002, p. 28.

6. "The most difficult thing about translating from one language into another is the tempo of its style, which is rooted in the character of the race physiologically speaking, in the average tempo of its "metabolism". There are honestly intended translations which, as involuntarily coarse versions of the original, are almost misrepresentations, simply because its brave and cheerful tempo, which springs over and neutralizes everything dangerous in things and words, cannot be translated."

Trans. R. J. Hollingdale - (PowerPoint version: published source unknown)

"All mental faculties intervene in the human cultural process, but [...] I chose to highlight the ability to make images, affect, and consciousness, because cultural minds are not conceivable without such faculties. Memory, language, imagination, and reasoning are leading participants in cultural processes, but require image making. As for the creative intelligence responsible for the actual practices and artifacts of cultures, it cannot operate without affect and consciousness. Curiously, affect and consciousness also happen to be the faculties that got away, forgotten in the throes of the rationalist and cognitive revolutions. They deserve special attention."

Damasio, Antonio R., The Strange Order of Things: Life, feeling and the making of cultures, Vol First edition, ebook, Vintage; 2018, p. 115 (Chap. 10, first paragraph). 


\section{Appendix Two}

The whole of $B G E$ Section 28:

"28. What is most difficult to render from one language into another is the TEMPO of its style, which has its basis in the character of the race, or to speak more physiologically, in the average TEMPO of the assimilation of its nutriment. There are honestly meant translations, which, as involuntary vulgarizations, are almost falsifications of the original, merely because its lively and merry TEMPO (which overleaps and obviates all dangers in word and expression) could not also be rendered. A German is almost incapacitated for PRESTO in his language; consequently also, as may be reasonably inferred, for many of the most delightful and daring NUANCES of free, free-spirited thought. And just as the buffoon and satyr are foreign to him in body and conscience, so Aristophanes and Petronius are untranslatable for him. Everything ponderous, viscous, and pompously clumsy, all long-winded and wearying species of style, are developed in profuse variety among Germans - pardon me for stating the fact that even Goethe's prose, in its mixture of stiffness and elegance, is no exception, as a reflection of the "good old time" to which it belongs, and as an expression of German taste at a time when there was still a "German taste," which was a rococo-taste in moribus et artibus. Lessing is an exception, owing to his histrionic nature, which understood much, and was versed in many things; he who was not the translator of Bayle to no purpose, who took refuge willingly in the shadow of Diderot and Voltaire, and still more willingly among the Roman comedy-writers-Lessing loved also free-spiritism in the TEMPO, and flight out of Germany. But how could the German language, even in the prose of Lessing, imitate the TEMPO of Machiavelli, who in his "Principe" makes us breathe the dry, fine air of Florence, and cannot help presenting the most serious events in a boisterous allegrissimo, perhaps not without a malicious artistic sense of the contrast he ventures to present-long, heavy, difficult, dangerous thoughts, and a TEMPO of the gallop, and of the best, wantonest humour? Finally, who would venture on a German translation of Petronius, who, more than any great musician hitherto, was a master of PRESTO in invention, ideas, and words? What matter in the end about the swamps of the sick, evil world, or of the "ancient world," when like him, one has the feet of a wind, the rush, the breath, the emancipating scorn of a wind, which makes everything healthy, by making everything RUN! And with regard to Aristophanes - that transfiguring, complementary genius, for whose sake one PARDONS all Hellenism for having existed, provided one has understood in its full profundity ALL that there requires pardon and transfiguration; there is nothing that has caused me to meditate more on "PLATO'S secrecy and sphinx-like nature, than the happily preserved petit fait that under the pillow of his death-bed there was found no "Bible," nor anything Egyptian, Pythagorean, or Platonic — but a book of Aristophanes. How could even Plato have endured life—a Greek life which he repudiated—without an Aristophanes!"

trans. Helen Zimmern, 1906, Project Gutenberg Ebook: Release Date: December 7 , 2009 [EBook \#4363] 